\title{
Estimation of Tobacco Products Price and Income Elasticity using Aggregate Data
}

\author{
Olivera Jovanović $^{1 *}$ ｜ Jovan Zubović ${ }^{1}$ ｜ Marko Vladisavljevićc ${ }^{1}$ | Duško Bodroža1 \\ Isidora Ljumović $^{\mathbf{1}}$ | Ivana Domazet ${ }^{\mathbf{1}}$ | Mihajlo Đukić ${ }^{\mathbf{1}}$ \\ ${ }^{1}$ Institute of Economic Science, Belgrade, Serbia
}

\begin{abstract}
The main aim of this paper is to estimate long run and short run price and income elasticity for cigarettes based on aggregate level data for period 2002-2016 using Error Correction model. In order to estimate elasticity of demand for tobacco products authors of this paper used aggregate level data. Because the cigarettes make the largest share in overall consumption of tobacco products in Serbia, conducted research is based on approach that $90 \%$ of total consumption of tobacco products are cigarettes. This research is unique in the SEE countries, while research conducted in other low and middle income countries in Western Balkan region showed similar results. Price elasticity among the SEE countries is in range between -0.44 and -0.78 Research among low and middle income countries over the world empirically showed that demand for tobacco products is usually inelastic. Analysis conducted in the Republic of Serbia showed that price elasticity ranged between -0.76 and -0.62 while income elasticity ranged between 0.34 and 0.39 .
\end{abstract}

Key words: tobacco products, consumption, elasticity, price

JEL Classification: E20, H20, C13

\section{INTRODUCTION}

In order to empirically estimate the long-term and short-term effects of increasing cigarettes price on cigarettes consumption in Serbia we have used the Error Correction model (ECM). This model is often used in research among countries with low and middle income to estimate price elasticity using macro aggregate data (Ross and Al-Sadat, 2007). Research nalysis aims to present price and income elasticity for tobacco products in Serbia using official statistical data for the period 2002-2016.

According to official Institute for Public Health "Batut" data more than one half of total population consumed tobacco products in a lifetime (Health and Statistical Yearbook for Serbia, 2018), while World Bank data shows that in 2017 at least 33\% population above age 15 in Serbia smokes at least one cigarette per day, amounting to about 2,457,000 active smokers (Tobacco Control Fact Sheet, Serbia). Thus, tobacco products' consumption in Serbia should be of high concern to policymakers. Results of empirical research shown in this paper can help policy makers (in the field of economics, finance and health) to understand the factors affecting the demand for cigarettes including their prices/taxes, others tobacco control policies, and income so that they can design policies to lower tobacco use in Serbia.

\footnotetext{
*Corresponding Author, e-mail: olivera.jovanovic@ien.bg.ac.rs
} 
The main obstacle in this analysis was the lack of data to construct a long time series. Given that only a short time series is available, we have carefully defined variables to assure that they are compatible and found the best methodological approach to deal with data deficiency. We opted for a classic linear model of cigarette demand with consumption per adult as a depended variable, while real tobacco price and real income are the primary independent variables. The model tested for the impact of various tobacco policies as well as for a summary index of tested tobacco control policies. Other relevant variables that could affect consumption such as tertiary education, life expectancy at birth for male and female, average employment and employment rates for male and female were also tested in the models but not included in the final specification and presentation of results due to concerns related to the degree of freedom.

\section{DATA}

Cigarette demand price and income elasticities were estimated using annual data. We have constructed several linear models of cigarette demand with a maximum of three independent variables to preserve the degree of freedom.

Cigarettes consumption and cigarette price data in Serbia are available only for the period after year 2002. Several measures of cigarette consumption and cigarette price have been accounted for and tested their properties to assess their suitability for our models.

The dependent variable is the annual cigarette consumption per capita of adult population ${ }^{1}$. This measure of aggregate cigarette consumption is calculated using retail sales volume as reported by the Statistical Office of the Republic of Serbia. Since the volume is measured in the sticks, we divided it by 20 to get cigarette consumption in packs (Figure 1).

We have also considered an estimate of consumption based on the Household Budget Survey data (HBS). However real consumption is underreporting in HBS data by a large amount and was therefore abandoned. Another possible measure of consumption can be derived from cigarette production added to net import and export level. This measure resulted in unstable estimates, most probably due to time lags of recording foreign trade, so we excluded it from further analysis.

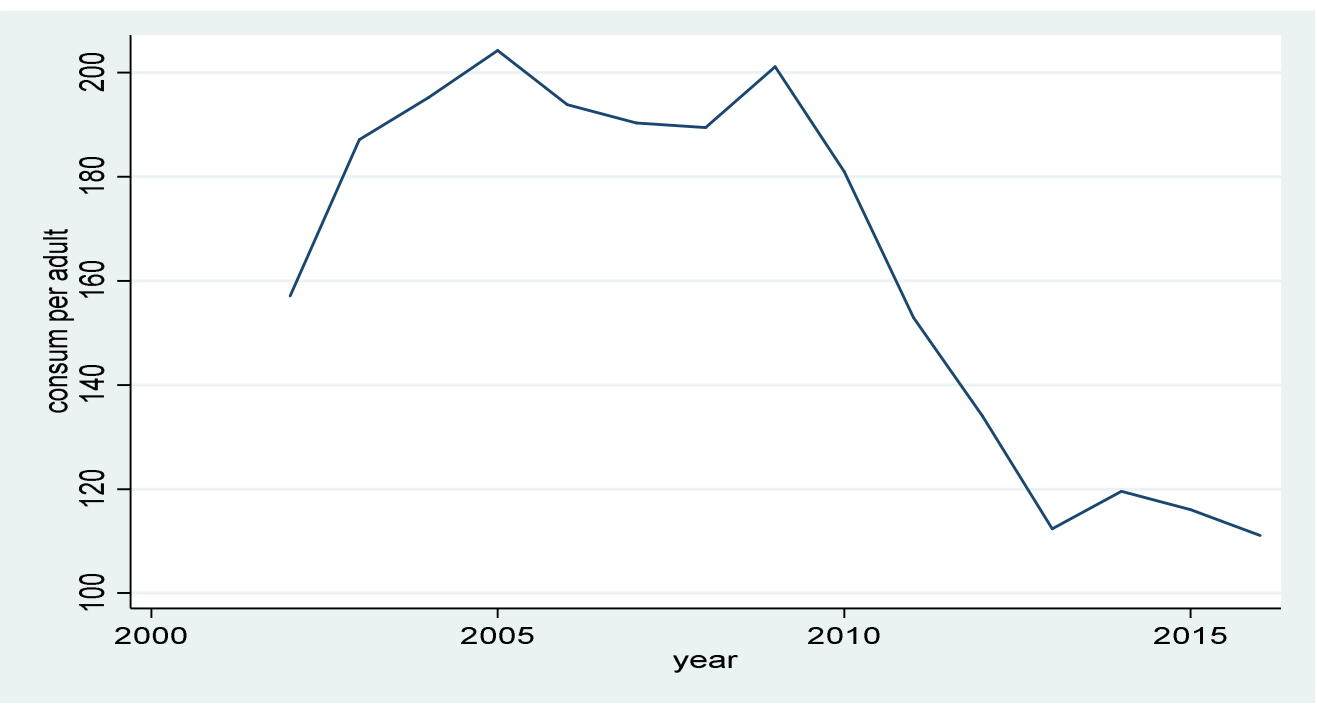

Figure 1. Cigarettes in packs per adult, 2002-2016

Source: Statistical Office of the Republic of Serbia

\footnotetext{
${ }^{1}$ Population of age 15 and older
} 
The most important independent variable is the price. We first considered official data on weighted average cigarette price and the price of the most sold brand $^{2}$, but their values do not exist for all years included in the model. Therefore, we opted for real (or relative) tobacco price index $^{3}$ (real tobacco CPI; Figure 2) that we obtained by deflating (using general CPI) nominal tobacco CPI published annually since 2007 by the Statistical Office.

Methodology for creating tobacco CPI was implemented in 2007 by Statistical Office of the Republic of Serbia. So we extended time series data using official Statistical Office methodology for calculation and extrapolation of real tobacco CPI. Real tobacco CPI in the period 2002-2016 is shown in figure 2.

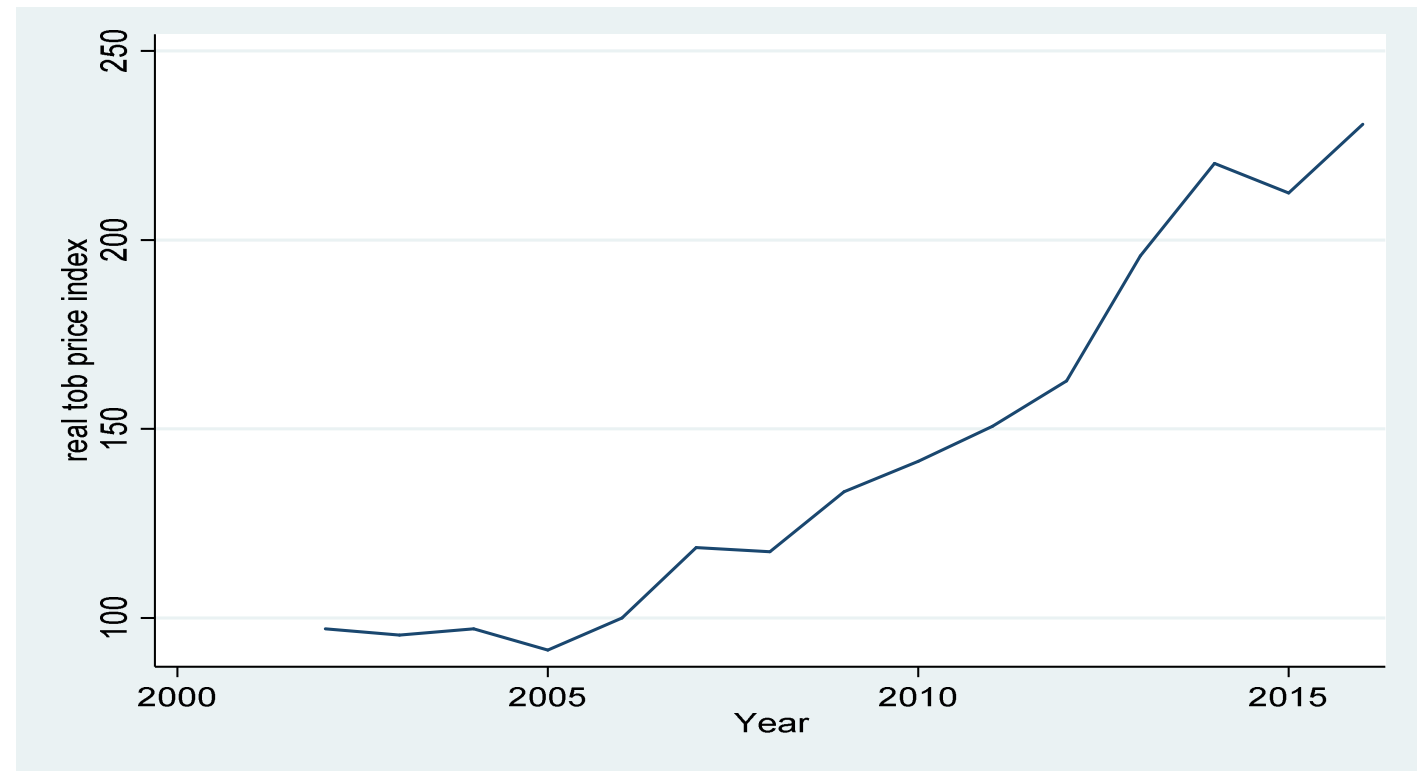

Figure 2. Tobacco price index (Real Tobacco CPI), 2002-2016

Source: Statistical Office of the Republic of Serbia

Real income was measured by real gross domestic product (GDP) per capita obtained from the Statistical Office of the Republic of Serbia.

\footnotetext{
${ }^{2}$ Available in Official Gazette of Republic of Serbia

3 Tobacco price index is official data available in Statistical Yearbook, published annually by Statistical Office of Republic of Serbia. It represents a retail price index of tobacco products, calculated by weights that present structure of household consumption of cigarette and other tobacco products. It is obtained from the data of HBS, National Accounts, Trade and Catering Trades statistics, particular ministries etc. Note that in Serbia, cigarettes are main consumed tobacco product. Because this index is available as chained, we converted into base index and extended time series.
} 


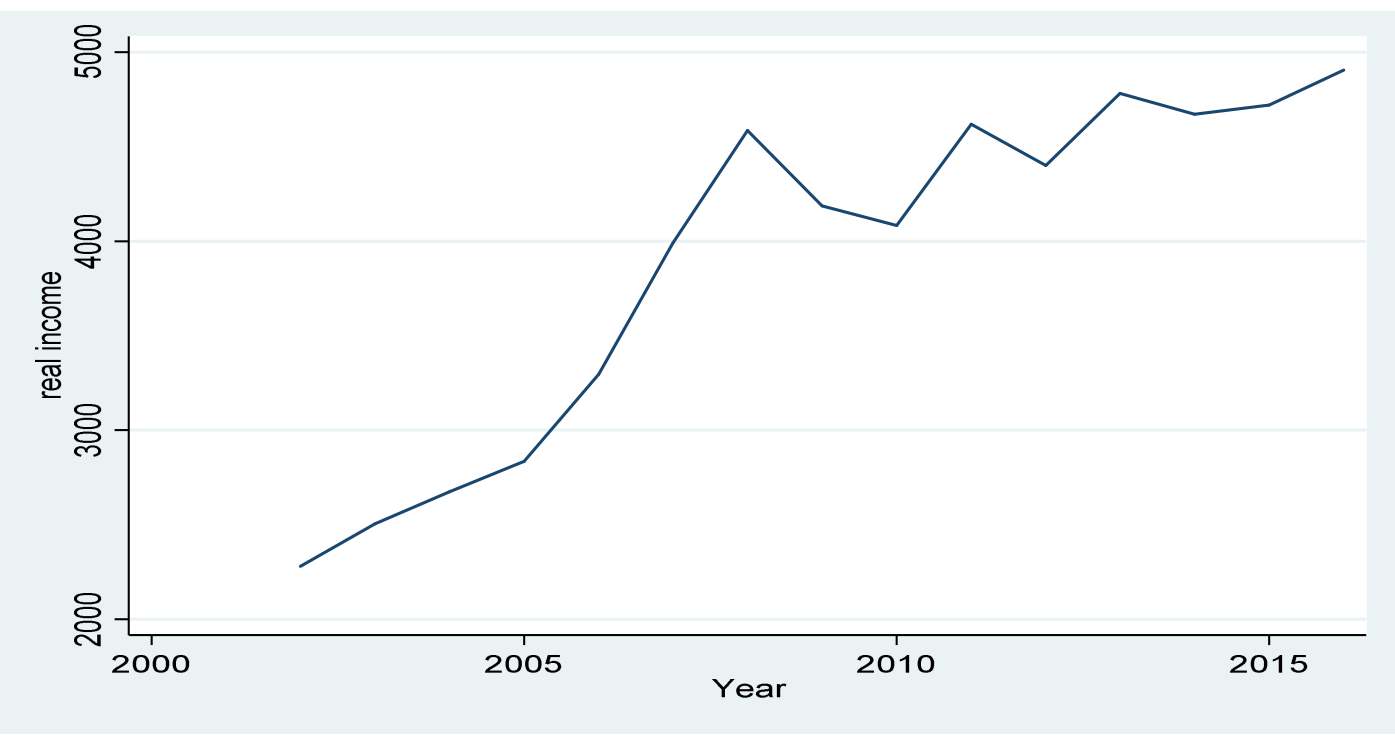

Figure 3. Real GDP per capita, 2002-2016

Source: Statistical Office of the Republic of Serbia

Tobacco control policies are an essential factor in the demand for cigarettes as well as for all other tobacco products consumption We have analyzed the impact of two policies in our models using dummy variables for the ban on smoking in all public indoor areas (value 0 before 2005, value 1 otherwise) and the ban on tobacco advertising (value 0 before 2010, value 1 otherwise). Effects of implementing regulatory policies were measured separately, including one by one variable in the model. We created a tobacco policy index by adding up the two dummy variables which represent the summary measure for tobacco control policies. Even though many factors influence the final price of cigarettes, the most essential policy-related determinants of cigarette prices are taxes (Chaloupka et al., 2010).

Chronically poor competitiveness of Serbian market during the global economic crisis has become a basic weakness of Serbian economy. Therefore, the negative effects of the crisis in Serbia felt widely, exposing the deep structural problems of Serbian economy (Domazet, Stošić, 2013). Those are reasons why we decided to include in analysis several variables more. Current socioeconomic environment indicate the importance of employment (male and female) into our study (Đuričin, Pantić, 2015). We have used other independent variables such as the number of graduates with tertiary education (to measure impact of education on cigarette demand), average level of employment (an alternative measure of income and stress level) life expectancy at birth for male and female (to assess the impact of the return to the investment in health). Structural changes lead to changes in the level of employment, especially in the private sector (Ognjanović, 2013). In recent decades, women have successfully fought for their equality in society and proved they are capable of great achievements, so we used average level of employment for women in our study (Ljumović, Pavlović, 2017). However, results of the models including these variables are available upon request. Table 1 and Table 2 summarized the data used in our analysis. 
Table 1. Data used in the macro model of cigarette demand, 2002-2016

\begin{tabular}{|c|r|r|r|r|r|r|}
\hline Year & $\begin{array}{c}\text { Retail volume } \\
\text { (consumption of } \\
\text { cigarettes, packs } \\
\text { per adult)* }\end{array}$ & $\begin{array}{c}\text { Real tobacco } \\
\text { consumer } \\
\text { price index** }\end{array}$ & $\begin{array}{c}\text { Real GDP } \\
\text { per } \\
\text { capita*** }\end{array}$ & $\begin{array}{c}\text { Tobacco } \\
\text { Control Policy } \\
\text { Index }\end{array}$ & Law $^{\mathbf{1}}$ & Law $^{\mathbf{2}}$ \\
\hline 2002 & 157.11 & 97.10 & 2280 & 0 & 0 & 0 \\
\hline 2003 & 187.08 & 95.45 & 2505 & 0 & 0 & 0 \\
\hline 2004 & 195.17 & 97.11 & 2675 & 0 & 0 & 0 \\
\hline 2005 & 204.24 & 91.53 & 2836 & 1 & 1 & 0 \\
\hline 2006 & 193.77 & 100.00 & 3297 & 1 & 1 & 0 \\
\hline 2007 & 190.29 & 118.60 & 3990 & 1 & 1 & 0 \\
\hline 2008 & 189.42 & 117.54 & 4586 & 1 & 1 & 0 \\
\hline 2009 & 201.12 & 133.44 & 4187 & 1 & 1 & 0 \\
\hline 2010 & 180.89 & 141.50 & 4082 & 2 & 1 & 1 \\
\hline 2011 & 152.96 & 150.68 & 4619 & 2 & 1 & 1 \\
\hline 2012 & 133.96 & 162.75 & 4400 & 2 & 1 & 1 \\
\hline 2013 & 112.35 & 195.81 & 4781 & 2 & 1 & 1 \\
\hline 2014 & 119.55 & 220.32 & 4672 & 2 & 1 & 1 \\
\hline 2015 & 116.08 & 212.42 & 4720 & 2 & 1 & 1 \\
\hline 2016 & 111.12 & 230.61 & 4904 & 2 & 1 & 1 \\
\hline
\end{tabular}

*Source: Statistical Office of Republic of Serbia, 2017

**Source: Statistical Office of Republic of Serbia, 2017

***Source: Statistical Office of Republic of Serbia, 2017

Law 1 is The Law on the protection of the population from exposure to tobacco (2004)

Law 2 is Advertising Law (2009)

Table 2. Data used in the macro model of cigarette demand, control variables, 2002-2016

\begin{tabular}{|l|r|r|r|r|r|r|r|r|}
\hline Year & $\begin{array}{c}\text { Education, } \\
\text { graduated } \\
\text { students }\end{array}$ & $\begin{array}{c}\text { Life } \\
\text { expectancy } \\
\text { at birth, } \\
\text { female (\%) }\end{array}$ & $\begin{array}{c}\text { Life } \\
\text { expectancy } \\
\text { at birth, } \\
\text { male (\%) }\end{array}$ & $\begin{array}{c}\text { Life } \\
\text { expectancy } \\
\text { at birth, } \\
\text { total (\%) }\end{array}$ & $\begin{array}{c}\text { Employ- } \\
\text { ment } \\
\text { level, } \\
\text { average }\end{array}$ & $\begin{array}{c}\text { Employ- } \\
\text { ment } \\
\text { rate, } \\
\text { women }\end{array}$ & $\begin{array}{c}\text { Employ- } \\
\text { ment } \\
\text { rate, } \\
\text { male }\end{array}$ & $\begin{array}{c}\text { Employ- } \\
\text { ment } \\
\text { rate, } \\
\text { total }\end{array}$ \\
\hline 2002 & 18,709 & 75 & 69.7 & 72.3 & $2,207,903$ & 40.3 & 57.5 & 48.6 \\
\hline 2003 & 19,748 & 75.1 & 69.9 & 72.4 & $2,168,678$ & 38.7 & 56.9 & 47.6 \\
\hline 2004 & 22,047 & 75.5 & 70 & 72.7 & $2,166,949$ & 36.3 & 54.9 & 45.2 \\
\hline 2005 & 27,537 & 75.6 & 70.2 & 72.8 & $2,171,457$ & 32.9 & 52.4 & 42.3 \\
\hline 2006 & 29,406 & 76.1 & 70.8 & 73.4 & $2,115,135$ & 32.0 & 49.3 & 40.4 \\
\hline 2007 & 32,039 & 76.5 & 70.9 & 73.6 & $2,085,242$ & 33.8 & 50.3 & 41.8 \\
\hline 2008 & 34,671 & 76.6 & 71.3 & 73.9 & $2,081,676$ & 36.5 & 53.2 & 44.4 \\
\hline 2009 & 40,330 & 76.7 & 71.4 & 74.0 & $1,984,740$ & 34.0 & 49.1 & 41.2 \\
\hline 2010 & 43,545 & 77 & 71.8 & 74.3 & $1,901,198$ & 31.1 & 45.3 & 37.9 \\
\hline 2011 & 46,162 & 77.2 & 72 & 74.5 & $1,866,170$ & 29.0 & 43.1 & 35.8 \\
\hline 2012 & 47,523 & 77.5 & 72.3 & 74.8 & $1,865,614$ & 28.7 & 42.8 & 35.5 \\
\hline 2013 & 47,797 & 77.9 & 72.6 & 75.2 & $1,864,783$ & 30.8 & 45.2 & 37.7 \\
\hline 2014 & 58,728 & 78 & 72.8 & 75.3 & $1,845,494$ & 33.0 & 46.9 & 39.7 \\
\hline 2015 & 50,501 & 77.9 & 72.8 & 75.3 & $1,896,000$ & 35 & 50 & 43 \\
\hline 2016 & 50,326 & 77.8 & 72.8 & 75.2 & $1,921,000$ & 38 & 53 & 45 \\
\hline
\end{tabular}

Source: Statistical Office of Republic of Serbia, 2017 


\section{THE MODEL SPECIFICATION TESTS}

Conventional model in linear form is used to estimate the price and income elasticity of cigarette demand. All variables are used in real values.

(1) $Y_{t}=\alpha+\beta_{1} X_{1 t}+\beta_{2} X_{2 t}+\varepsilon_{t}$, where $t=1, \ldots, 15$

Where the following represent:

$\mathrm{Y}_{\mathrm{t}}$ - cigarette consumption per adult (retail sales volume in packs, per adult)

$\mathrm{X}_{1 \mathrm{t}}$ - real tobacco price index (real tobacco $\mathrm{CPI}$ )

$\mathrm{X}_{2 \mathrm{t}}$-real gross domestic product per capita (real GDP per capita)

$\beta_{1}$ - price coefficient

$\beta_{2}$ - income coefficient

Model (1) includes only price and income measures as independent variables. Therefore, their coefficients represent the upper bound, since the impact of tobacco control variables is not taken into account.

Model (2) is similar to Model (1), but includes tobacco control policy. In this case, we used variable tban (law2) to reflect the adoption of the Advertising Law (ban on advertising of tobacco products). $\mathrm{B}_{3}$ is a coefficient capturing the impact of advertising law on cigarette consumption.

(2) $Y_{t}=\alpha+\beta_{1} X_{1 t}+\beta_{2} X_{2 t}+\beta_{3} X_{3 t}+\varepsilon_{t}, \quad$ where $t=1, \ldots, 15$

We estimated several versions of demand model with tobacco control policies/event to find an adequate specification, but because the analysis is limited with the degrees of freedom, all individual policies could not be included in just one model. Besides variable tban which is used in the model (2), variable tlaw1 (law on the protection of the population from exposure to tobacco) is implemented in the model (3). Tobacco control policy index (tpi) defined as the sum of the other two indicators is used in the model (4). Apart from these variables, we took into consideration life expectancy at birth ${ }^{4}$ (total) in estimated model $5^{5}$. Because life expectancy at birth of a female is not integrated at the same order as dependent and independent variables, we did not use it in final estimation of cigarette demand.

The diagnostics of variables listed in Table 1 starts with stationarity unit root tests. The classic analysis of time series is based on the assumption that the data are stationary, which implies a constant mean and a constant variance over time. The time series is stationary if the following conditions are satisfied:

1) $\mathrm{E}\left(\mathrm{X}_{\mathrm{t}}\right)=$ const, $\mathrm{t}=1,2,3 \ldots$

2) $v\left(X_{t}\right)=$ const, $t=1,2,3 \ldots$

3) $\operatorname{cov}\left(X_{t}, X_{t-k}\right)=f(k) \cdot t=1,2,3 \ldots k=1,2 \ldots$

In practice, many time series do not meet this requirement. For example, a random shock that would weaken its impact over time in case of a stationary series can have a permanent effect for an indefinite period if the time series is not stationary (or has a unit root). To test for stationarity, we used Dickey-Fuller (DF) statistics for the presence of unit root (Mladenović and Nojković, 2007).

We tested two main hypotheses in the first step:

\footnotetext{
${ }^{4}$ Life expectancy at birth is average number of years a newborn is expected to live if mortality patterns at the time of its birth remain constant in the future.

5 Dickey-Fuller test results are presented in Table 2.
} 
$\mathrm{H}_{0}$ : Time series is not stationary, has a unit root

$\mathrm{H}_{1}$ : Time series is stationary

The result for a level order of integration shows that we cannot accept $\mathrm{H}_{\mathrm{o}}$ hypothesis that the variables are stationary because DF statistic is above than all critical values. Therefore, we proceeded with the second step and tested hypothesis.

The test revealed that cigarette consumption, price and income are stationary in their first differences and are integrated at first order (I) (Table 3).

Table 3. Results of DF unit root test

\begin{tabular}{|c|c|c|c|}
\hline \multirow{4}{*}{ Variables } & \multicolumn{3}{|c|}{ Dickey-Fuller } \\
\hline & \multicolumn{2}{|c|}{ ADF t-test statistic } & \multirow{2}{*}{$\begin{array}{c}\text { Level/first } \\
\text { dif. }\end{array}$} \\
\hline & \multicolumn{2}{|c|}{$\mathrm{H}_{0}$ : variable has a unit root } & \\
\hline & Level Z(t) & First dif. $Z(t)$ & Decision \\
\hline \multicolumn{4}{|l|}{ Main variable } \\
\hline Consumption & -0.102 & $-3.029 * *$ & $\mathrm{I}(1)$ \\
\hline Real tobacco CPI & 0.988 & $-3.278^{* *}$ & $\mathrm{I}(1)$ \\
\hline GDP per capita & -1.526 & $-3.492^{* *}$ & $\mathrm{I}(1)$ \\
\hline \multicolumn{4}{|c|}{ Control variable } \\
\hline Tobacco Policy Index & -1.412 & $-3.986^{* * *}$ & $\mathrm{I}(1)$ \\
\hline tlaw1 (Regulator policy 1) & -2.171 & $-3.606^{* *}$ & $\mathrm{I}(1)$ \\
\hline tban (Regulator policy 2) & 0.857 & $-3.606^{* *}$ & $\mathrm{I}(1)$ \\
\hline Employment, average & -1.411 & -2.071 & $\mathrm{I}(2)$ \\
\hline Employment rate, total & -1.755 & -1.605 & $\mathrm{I}(2)$ \\
\hline Employment rate, male & -1.829 & -1.385 & $\mathrm{I}(2)$ \\
\hline Employment rate, female & -1.650 & -1.678 & $\mathrm{I}(2)$ \\
\hline Education-graduated students & -1.236 & $-4.787^{* * *}$ & $\mathrm{I}(1)$ \\
\hline Life expectancy at birth, (male) & -1.137 & $-3.739 * * *$ & $\mathrm{I}(1)$ \\
\hline Life expectancy at birth, (female) & -1.688 & -2.317 & $\mathrm{I}(2)$ \\
\hline Life expectancy at birth, (total) & -1.398 & $-2.979^{*}$ & $\mathrm{I}(1)$ \\
\hline
\end{tabular}

Note: $Z(t)$ is compared with corresponding test critical values; ${ }^{* * *}$ indicates rejection of $H_{0}$ at the $1 \%$ significance level, ${ }^{* *} 5 \%$ significance level, and ${ }^{*} 10 \%$ significance level.

Source: authors own calculation

Based on the results presented in Table 2, we observe that measure of cigarette consumption in Serbia is integrated at first order I(1), it is stationary at first differences since the reported value of Z(t) test statistic was -3.029 , on 5\% significance level. Real tobacco CPI and real GDP per capita are integrated at first order I(1) at $5 \%$ significance level, with reported $\mathrm{Z}(\mathrm{t})$ test statistic values: 3.278 and -3.429 , respectively. Tobacco control policy index, and individual regulatory variables tlaw1 and tban are integrated at same order as main independent variables I(1), all significant at $1 \%$ and $5 \%$ level. Different measures of employment in Serbia cannot be included in the further analysis, because DF test results show integration at second order I(II). DF test statistics for employment rate female is $\mathrm{Z}(\mathrm{t})=-2.695, \mathrm{p}=0.023$, employment rate male is $\mathrm{Z}(\mathrm{t})=-3.406, \mathrm{p}=0.007$ and for employment rate total is $\mathrm{Z}(\mathrm{t})=-2.988, \mathrm{p}=0.014$. $^{6}$

\footnotetext{
${ }^{6}$ Results of DF test shows us that variables of employment are not integrated at first difference.
} 
To determine the existence of a long-term relationship between our variables of interest, we applied a test for cointegration- Dickey-Fuller residual tests (DFR). If the time series are cointegrated, then the residual series is stationary, while the non-stationarity of the residual means that the time series are not cointegrated. If a $\mathrm{H}_{0}$ hypothesis is accepted than the residuals are nonstationary and the time series are not co-integrated. The rejection of the zero hypotheses $\left(\mathrm{H}_{0}\right)$ confirms the stationarity of the residual, and therefore the cointegration of given time series.

Using the DFR test, we found that the variables in models (1), model (2) and model (4) are cointegrated and thus, they have a long-run relationship. To confirm this result, we applied another test for cointegration, Johansen cointegration test (Johansen, 2005).

Table 4 present results of the Johansen cointegration test for variables in authors preferred models- model (1), model (2) and model (4).

Table 4, Results of Johansen co-integration tests.

\begin{tabular}{|c|c|c|c|c|c|}
\hline \multicolumn{6}{|l|}{ Model 1} \\
\hline Null Hypotheses & Eigenvalue & $\begin{array}{c}\text { Trace } \\
\text { Statistic }\end{array}$ & $\begin{array}{c}0.05 \\
\text { Critical } \\
\text { Value }\end{array}$ & Max-Eigen & $\begin{array}{c}0.05 \\
\text { Critical } \\
\text { Value }\end{array}$ \\
\hline H0: $(\mathbf{R}=0)^{*}$ & 0.0000 & 23.2142 & 24.3100 & 14.4272 & 177.8900 \\
\hline H0: $(R \leq 1)$ & 0.6432 & 8.7869 & 12.5300 & 8.7478 & 11.4400 \\
\hline HO: $(R \leq 2)$ & 0.4647 & 0.0392 & 3.8400 & 0.0392 & 3.8400 \\
\hline \multicolumn{6}{|c|}{ Model 2} \\
\hline H0: $(R=0)$ & 0.0000 & 45.5888 & 39.8900 & 25.2938 & 23.8000 \\
\hline H0: $(\mathrm{R} \leq 1)^{*}$ & 0.8358 & 20.2950 & 24.3100 & 13.4566 & 17.8900 \\
\hline H0: $(R \leq 2)$ & 0.3748 & 6.8385 & 12.5300 & 6.5662 & 11.4400 \\
\hline \multicolumn{6}{|c|}{ Model 4} \\
\hline HO: $(R=0)$ & 0.0000 & 57.0688 & 39.8900 & 29.1951 & 23.8000 \\
\hline H0: $(R \leq 1)$ & 0.8757 & 27.8737 & 24.3100 & 17.1833 & 17.8900 \\
\hline H0: $(\mathrm{R} \leq 2)^{*}$ & 0.7069 & 10.6904 & 12.5300 & 10.4773 & 11.4400 \\
\hline
\end{tabular}

Note: Johansen, S. 1995. Likelihood-Based Inference in Cointegrated Vector Autoregressive Models. Oxford: Oxford University Press.

$R$ is the number of the cointegrating equation. *indicates the rejection of the null hypothesis at the $5 \%$ level. Source: authors own calculation

Results of Max-Eigen and Trace statistics indicate that $\mathrm{H}_{0}$ of no cointegration vector can be rejected and that there exists one co-integration equation at the $5 \%$ significance level in Model 1.

After stationarity and cointegration tests, we proceed with estimating long-run and short-run relationships. Engle-Granger two step method is used to estimate long run and short run price and income elasticities. First, long-run relationships between cigarette consumption, price and income is estimated using the classic linear demand model (equations 1.1 and 1.2) Because models are specified in linear form, price and income elasticity is calculated multiplying the estimated price and income coefficient $\beta_{1}$ and $\beta_{2}$ by price and income fitted values, divided by fitted value of cigarette consumption in packs. The use of fitted values instead of actual average values is required to obtain results based on the long run equilibrium (Ross and Al-Sadat, 2007).

Since cointegration exists in observed models, we estimated the second step of the EngleGranger method - the Error Correction Model (ECM) - to estimate short-run price and income elasticities (Ross and Al-Sadat, 2007). This model used the first difference of all variable and 
lagged residual from the long-run model (Mladenović and Petrović, 2007). The short-run ECM model can be expressed as follows (Mladenović and Nojković, 2012):

$$
\begin{aligned}
\Delta Y_{t} & =\gamma_{0} u_{t-1}+\gamma_{11} \Delta Y_{t-1}+\ldots \gamma_{1 k} \Delta Y_{t-k}+\gamma_{21} \Delta P_{t-1}+\ldots+\gamma_{2 k} \Delta P_{t-k} \\
& +\gamma_{31} \Delta I_{t-1}+\ldots+\gamma_{3 k} \Delta I_{t-k}+\gamma_{41} \Delta Z_{t-1}+\ldots+\gamma_{4 k} \Delta Z_{t-k}+\varepsilon_{1 t}
\end{aligned}
$$

where $\mathrm{k}$ represents the number of lags; $\Delta$ is the difference operator; $\gamma$ 's are parameters to be estimated; $\varepsilon_{1 t}$ is the error term; $u_{t-1}$ is error correction term that represents residuals from the long-run equation, and $\gamma_{0}$ measures the speed of adjustment toward equilibrium in long-run. In our specification of ECM model, we choose to use one lag to avoid losing too many degrees of freedom because our time series are short (a small number of observations).

$$
\begin{aligned}
& \Delta Y_{t}=\gamma_{0} u_{t-1}+\gamma_{1} \Delta P_{t-1}+\gamma_{2} \Delta I_{t-1}+\varepsilon_{1 t} \\
& \Delta Y_{t}=\gamma_{0} u_{t-1}+\gamma_{1} \Delta P_{t-1}+\gamma_{2} \Delta I_{t-1}+\gamma_{3} \Delta \text { tban }_{t-1+} \varepsilon_{1 t}
\end{aligned}
$$

ECM model for cigarette demand which includes only measures of tobacco price and income is given with equation 1.4. The equation for cigarette demand model which includes tobacco control policy index or regulatory variables like tban or law1 is given in 1.5. Since we are using lin-lin form, price and income elasticities are calculated using lin-lin form of the model:

\begin{tabular}{|c|c|c|c|c|c|}
\hline & 1 (basic) & 2 (tban) & 3 (tlaw1) & 4 (tpi) & 5 (lifetotal) \\
\hline VARIABLES & consumption & consumption & consumption & consumption & consumption \\
\hline rtobcpi & -0.86335 & -0.6995449 & -0.7958605 & -0.8467552 & -0.7820187 \\
\hline GDPpc & 0.01406 & 0.0150893 & 0.0046155 & 0.0161606 & 0.019342 \\
\hline $\begin{array}{l}\text { Regulatory } 1 \\
\text { (tban) }\end{array}$ & & -20.07846 & & & \\
\hline $\begin{array}{l}\text { Regulatory } 2 \\
\text { (tlaw1) }\end{array}$ & & & 18.38403 & & \\
\hline $\begin{array}{l}\text { Regulatory } \\
\text { (policy index) }\end{array}$ & & & & -3.70036 & \\
\hline $\begin{array}{l}\text { Life expectancy } \\
\text { at birth, total }\end{array}$ & & & & & -7.962421 \\
\hline Constant & 232.7062 & 214.455 & 245.1503 & 226.8379 & 789.4529 \\
\hline Observations & 15 & 15 & 15 & 15 & 15 \\
\hline $\begin{array}{l}\text { Dickey-Fuller } \\
\text { test for unit } \\
\text { root - residuals }\end{array}$ & Test statistic & Test statistic & Test statistic & Test statistic & Test statistic \\
\hline
\end{tabular}

\section{RESULTS}

Table 5 presents results of the long-run cigarette demand for several different demand models.

Table 5. Long-run cigarette demand function 


\begin{tabular}{|l|r|r|r|r|r|}
\hline & $\mathbf{1}$ (basic) & $\mathbf{2}$ (tban) & $\mathbf{3}$ (tlaw1) & $\mathbf{4}$ (tpi) & $\mathbf{5}$ (lifetotal) \\
\hline VARIABLES & consumption & consumption & consumption & consumption & consumption \\
\hline Adj. R-squared & $\mathrm{Z}(\mathrm{t})=-3.323$ & $\mathrm{Z}(\mathrm{t})=-3.671$ & $\mathrm{Z}(\mathrm{t})=-3.247$ & $\mathrm{Z}(\mathrm{t})=-3.419$ & $\mathrm{Z}(\mathrm{t})=-3.465$ \\
\hline $\begin{array}{l}\text { Dickey-Fuller } \\
\text { test for unit } \\
\text { root - residuals }\end{array}$ & & & & & \\
\cline { 2 - 6 } $\begin{array}{l}\text { Hausman test } \\
\text { m-statistic }\end{array}$ & ------ & ------ & $\mathrm{m}=0.04$ & $\mathrm{~m}=0.64$ & $\mathrm{~m}=0.04$ \\
\hline
\end{tabular}

Note: $t$-statistics in brackets; ${ }^{* * *} p<0.01,{ }^{* *} p<0.05,{ }^{*} p<0.1$;

Source: authors own calculation

All variables in model 1 are statistically significant. This model is the basic model, because it includes only two independent variables, without any other controls. Real tobacco price index has a negative sign, which is in line with the economic theory - if the price of cigarettes increases, their consumption will go down. Real income has a positive sign which is also in line with the economic theory of normal good - the higher the income, the higher the consumption. $\mathrm{R}^{2}$ value is 0.845 , meaning that $84.5 \%$ variability in the model is explained with selected variables.

Real tobacco price index and real income in model 2 are statistically significant with sings similar to model 1. Variable tban which represents one tobacco control policy (ban on tobacco advertising) is not statistically significant, but it's inclusion leads to the improvement in $\mathrm{R}^{2}$ value. The statistical insignificance of the policy variable can be explained by the short length of the time series.

In model 3, variable tlaw1 is not statistically significant $(\mathrm{p}=0.317)$, and it has the opposite sign. The tobacco policy index (tpi) in Model 4 is also not statistically significant ( $p=0.760)$, but it has the expected sign.

In model 5 we include life expectancy at birth (total), and results show that variable is not statistically significant $(\mathrm{p}=0.730)$, but has a negative coefficient sign. It is expected result even if we did not get significant in the model, one of reason can be a very short and limited time-series data.

The values of long-run price elasticities for our favorite models are shown in Table 6, including the results bootstrapping.

Table 6. Long-term price and income elasticity for tobacco products

\begin{tabular}{|l|r|r|r|}
\hline Long-run & \multicolumn{1}{|c|}{ Model 1 } & \multicolumn{1}{c|}{ Model 2 } & \multicolumn{1}{c|}{ Model 4 } \\
\hline Price elasticity & $\mathbf{- 0 . 7 6 4 4 0 8}$ & $\mathbf{- 0 . 6 1 9 3 6 8 7}$ & $\mathbf{- 0 . 7 4 9 7 0 7}$ \\
\hline Price elasticity bootstrapped (100 replication) & $\begin{array}{r}-0.7808978 \\
(0.1583772)\end{array}$ & $\begin{array}{r}-0.5985788 \\
(0.2150423)\end{array}$ & $\begin{array}{r}-0.7562662 \\
(0.1607641)\end{array}$ \\
\hline Income elasticity & $\mathbf{0 . 3 3 6 8 1 9 1}$ & $\mathbf{0 . 3 6 1 2 2 8 5}$ & $\mathbf{0 . 3 8 6 8 7 3 2}$ \\
\hline $\begin{array}{l}\text { Income elasticity bootstrapped (100 } \\
\text { replication) }\end{array}$ & $\begin{array}{r}0.3461998 \\
(0.0085674)\end{array}$ & $\begin{array}{r}0.3972342 \\
(0.0085617)\end{array}$ & $\begin{array}{r}0.4354273 \\
(0.0139486)\end{array}$ \\
\hline
\end{tabular}

Note: SE in brackets

Source: authors own calculation

The long-run price elasticity in Model 1 is -0.764 , which is in line with results obtained in other low- and middle-income countries. This implies that $1 \%$ increases in prices of cigarettes lead to a $0.76 \%$ decrease in cigarette demand. Price elasticity is higher in model 1 than model 2, because this specification does not control the impact of tobacco control policies. 
The value of long-run income elasticity coefficient was 0.34 which implies that $1 \%$ increases in real GDP per capita lead to a $0.34 \%$ increase in cigarette demand.

When variable tban is included in the model (model 2), the value of long-run price elasticity coefficient is -0.62 which implies that $1 \%$ increases in prices of cigarettes led to a $0.62 \%$ decrease in cigarette demand. The value of long-run income elasticity coefficient was 0.36 and implies that $1 \%$ increases in real GDP per capita led to a $0.36 \%$ increase in cigarette demand. However, this result is not statistically significant. When variable tpi is included in model 4 , the value of price elasticity is -0.75 which is almost similar to basic model 1 . Value of income elasticity is 0.38 but this result also is not statistically significant.

Table 7. Short run cigarette demand function

\begin{tabular}{|c|c|c|c|}
\hline & Model 1 & Model 2 & Model 4 \\
\hline VARIABLES & D.consumption & D.consumption & D.consumption \\
\hline \multirow[t]{2}{*}{ D.rtobcpi } & $-0.8802679^{* *}$ & $-0.8574294^{* * *}$ & $-0.8563312^{* *}$ \\
\hline & -2.67 & -3.41 & -2.63 \\
\hline \multirow[t]{2}{*}{ D.GDPpc } & -0.0049126 & -0.0004975 & -0.0012268 \\
\hline & -0.45 & -0.05 & -0.1 \\
\hline \multirow[t]{2}{*}{ D.regulatory (D.tban) } & & -2.107591 & \\
\hline & & -0.17 & \\
\hline \multirow[t]{2}{*}{ D.regulatory (D.tpi) } & & & 4.280726 \\
\hline & & & 0.37 \\
\hline \multirow[t]{2}{*}{ L.Residuals } & $-0.7381731 * *$ & $-0.9576962^{* * *}$ & $-0.8358793^{* *}$ \\
\hline & -2.68 & -3.67 & -2.68 \\
\hline \multirow[t]{2}{*}{ Constant } & 5.581537 & 4.85751 & 4.040065 \\
\hline & 1.13 & 1.19 & 0.71 \\
\hline Observations & 14 & 14 & 14 \\
\hline R-squared & 0.517 & 0.7284 & 0.5679 \\
\hline Adj. R-squared & 0.3721 & 0.6077 & 0.3759 \\
\hline $\begin{array}{l}\text { Breusch-Pagan/ Cook- } \\
\text { Weisberg test for } \\
\text { heteroskedasticity }\end{array}$ & $\operatorname{chi} 2(1)=0.43$ & $\operatorname{chi} 2(1)=0.15$ & $\operatorname{chi} 2(1)=0.09$ \\
\hline Ho: Constant variance & Prob $>$ chi $2=0.5140$ & Prob $>$ chi2 $=0.7023$ & Prob $>$ chi $2=0.7612$ \\
\hline $\begin{array}{l}\text { Durbin's alternative } \\
\text { test for } \\
\text { autocorrelation }\end{array}$ & $\operatorname{chi} 2(1)=0.0023$ & $\operatorname{chi} 2(1)=0.168$ & $\operatorname{chi} 2(1)=5.568$ \\
\hline \multirow[t]{2}{*}{$\begin{array}{l}\text { H0: no serial } \\
\text { correlation }\end{array}$} & Prob $>$ chi2 $=9.290$ & Prob $>$ chi $2=0.6815$ & Prob $>$ chi $2=0.0174$ \\
\hline & Lags 1 & Lags 1 & Lags1 \\
\hline $\begin{array}{l}\text { Breusch-Godfrey LM } \\
\text { test for } \\
\text { autocorrelation }\end{array}$ & $\operatorname{chi} 2(1)=0.0077$ & $\operatorname{chi} 2(1)=0.289$ & $\operatorname{chi} 2(1)=5.800$ \\
\hline $\begin{array}{l}\text { H0: no serial } \\
\text { correlation }\end{array}$ & Prob $>$ chi2 $=7.111$ & Prob $>$ chi $2=0.5911$ & Prob $>$ chi $2=0.0160$ \\
\hline & Lags 1 & Lags 1 & Lags 1 \\
\hline
\end{tabular}




\begin{tabular}{|l|r|r|r|}
\hline Ramsey RESET test & $\mathrm{F}(3,6)=2.77$ & $\mathrm{~F}(3,6)=0.10$ & $\mathrm{~F}(3,6)=1.43$ \\
\hline $\begin{array}{l}\text { Ho: } \text { model has no } \\
\text { omitted variables }\end{array}$ & Prob $>\mathrm{F}=0.1205$ & Prob $>\mathrm{F}=0.9565$ & Prob $>\mathrm{F}=0.3238$ \\
\hline $\begin{array}{l}\text { Skewness/Kurtosis } \\
\text { tests for Normality }\end{array}$ & adj chi2(2)=2.97 & adj chi2 $(2)=3.96$ & adj chi2 $(2)=0.87$ \\
\hline Ho: normality & Prob>chi2=0.2264 & Prob $>$ chi2 $=0.1404$ & Prob $>$ chi2 $=0.6484$ \\
\hline $\begin{array}{l}\text { Jarque-Bera normality } \\
\text { test }\end{array}$ & $\mathrm{Chi}(2)=1.084$ & $\mathrm{Chi}(2)=.6345$ & $\mathrm{Chi}(2)=.6974$ \\
\hline Ho: normality & Prob>chi2=.5817 & Prob $>\operatorname{chi} 2=0.9099$ & Prob $>$ chi2 $=.7209$ \\
\hline Mean VIF & 1.19 & 1.37 & 1.4 \\
\hline
\end{tabular}

Note: $t$-statistics in brackets; ${ }^{* * *} p<0.01,{ }^{* *} p<0.05,{ }^{*} p<0.1$;

Source: authors own calculation

The results presented in Table 7 shows a negative real tobacco CPI coefficient in all models. It means that an increase in cigarette price in the short run will have a negative effect on consumption. Income coefficient in all models (models 1, 2 and 4) are negative, but not significant, so in a short-run increase of real GDP per capita leads to decrease in cigarette consumption. Estimated parameters for price in all three models are statistically significant at $5 \%$ and $1 \%$ level, while estimated parameters for income in all three models are not statistically significant. Coefficient for a regulatory variable tban has no statistically significant effect on the tobacco consumption, but has a negative sign. Same sign has a tobacco control policy index in model 4 . Negative sign of tobacco control policy variables in models is in line with the assumption that tobacco control policies leads to decrease cigarette consumption in a short run.

Error correction parameters values are $-0.738,-0.957,-0.836$ for models 1,2 and 4 respectively ${ }^{7}$. Interpretation of these coefficients is that $73.8 \%$ to $95.7 \%$ deviation from long-run equilibrium will be corrected in the following year.

The diagnostic test was applied in order to analyze the presence of heteroscedasticity, autocorrelation, multicollinearity and specification of functional form. Also, the normality of residuals is checked with Jarque-Bera and Skewness/Kurtosis tests (Mladenović and Nojković, 2012). Results of all specification tests are presented in Table 7.

The short-run elasticities of cigarette demand are presented in Table 8.

Table 8 Short run price and income elasticities

\begin{tabular}{|l|r|r|r|}
\hline Short-run & \multicolumn{1}{|c|}{ Model 1 } & \multicolumn{1}{c|}{ Model 2 } & \multicolumn{1}{c|}{ Model 4 } \\
\hline Price elasticity & -0.05 & -0.05 & -0.05 \\
\hline Income elasticity & -0.01 & -0.001 & -0.001 \\
\hline
\end{tabular}

Source: authors own calculation

In the short-run model, real tobacco CPI is statistically significant, and it implies that changes in price have an impact on the demand for cigarettes even in the short run. Short-run price elasticity is quite low, which is quite common for addictive products such as cigarettes (Ross and Al-Sadat, 2007) since consumers may need some time to quit. On the other hand, real income does not have a significant impact on cigarettes consumption, so we can conclude that in short-period of time smokers in Serbia will change their consumption of cigarettes. The impact of price and income changes in a short run is smaller compared to the long-run, as expected. We were not able

\footnotetext{
7 Error correction parameters are statistically significant on $5 \%$ and $1 \%$ level, respectively.
} 
to do bootstrap standard errors for the short-term price elasticities, because we have an insufficient number of observations.

\section{CONCLUSION}

Tobacco taxes are the most effective measure for preventing initiation and reducing tobacco consumption. Studies about tobacco taxation topic provide evidence that higher tobacco prices lead to a significant reduction in tobacco products consumption. These studies estimate the price elasticity of consumption in the range from -0.25 to -0.50 , but the estimates for low- and middleincome countries are higher (Chaloupka et al., 2010). Ross and Al-Sadat (2007) suggest that in low- and middle-income countries a $10 \%$ increase in cigarette prices can reduce cigarette consumption by $4 \%-8 \%$.

The results presented in this study represent the first estimates of the price and income elasticities of cigarette demand in the Republic of Serbia. We used official data from the Statistical Office of the Republic of Serbia for this analysis covering the period 2002-2016. We found that $10 \%$ increase in cigarette prices would reduce cigarette consumption by $6.2 \%-7.6 \%$ in the longrun, and by $0.5 \%$ in the short-run. This means that the total cigarette demand would decline by $6.7 \%$ to $8.1 \%$ in response to a $10 \%$ increase in price. Based on empirical research, price elasticity for cigarettes in Serbia is quite similar to other low and middle income countries who estimate price elasticity using the same methodology.

Even though research was conducted on a small number of observations (short time-series), our results correspond to the results obtained in other low- and middle-income countries. This confirms that higher tobacco taxes that lead to higher cigarette prices have the potential to reduce cigarette use in Serbia substantially. This would be desirable given the large toll of tobacco use on both public health and the economy.

\section{ACKNOWLEDGEMENTS}

This paper is a result of international research project "Accelerating progress in taxation of tobacco and tobacco products in low- and middle-income countries". This research is funded by the University of Illinois at Chicago's Institute for Health Research and Policy through its partnership with the Bloomberg Philanthropies.

\section{REFERENCES}

Chaloupka IV, F. J., Peck, R., Tauras, J. A., Xu, X., \& Yurekli, A. (2010). Cigarette excise taxation: the impact of tax structure on prices, revenues, and cigarette smoking (No. w16287). National Bureau of Economic Research.

Domazet, I., Stošić, I. (2013). "Strengthening the competitiveness of Serbian economy and the corporate market restructuring", Economic Analysis, Vol. 46, No 3/4, pp. 108-124.

Đuričin S., Pantić 0. (2015). "The Development of Micro-Crediting as a factor of Promoting Women Entrepreneurship in Serbia", Journal for Women Entrepreneurship and Education (JWEE), no1/2, pp. 50-66.

Hjalmarsson E., Österholm P. (2007), Testing for Cointegration Using the Johansen Methodology when Variables are Near-Integrated, IMF Working Paper, Western Hemisphere Division.

Johansen, S. 1995. Likelihood-Based Inference in Cointegrated Vector Autoregressive Models. Oxford: Oxford University Press.

Ognjenović K. (2013) 'How structural changes affect enterprises' expectations about employment in Serbia", Economic Analysis, Vol. 46, No 3/4, pp. 141-152.

Mladenović Z., Nojković A. (2012), Primenjena analiza vremenskih serija, Centar za izdavačku delatnost Ekonomskog fakulteta u Beogradu 
Mladenović Z., Petrović P. (2007), Uvod u ekonometriju, Centar za izdavačku delatnost, Ekonomski fakultet Univerziteta u Beogradu

Pavlović D., Ljumović I. (2016), "Prospects and Challenges for Female Leaders from the Balkans", Journal for Women Entrepreneurship and Education (JWEE), no1/2, pp. 58-75.

Ross, H., \& Al-Sadat, N. A. (2007). Demand analysis of tobacco consumption in Malaysia. Nicotine \& tobacco research, 9(11), 1163-1169.

Article history: $\quad$ Received: November 20, 2018

Accepted: December 13, 2018 